\title{
Developing Reading Materials Based on Local Wisdom
}

\author{
Elva Utami* and Lisa Rakhmanina
}

\author{
Prof Dr Hazairin SH University, Bengkulu, Indonesia \\ *Corresponding author. Email: utamielva80@gmail.com
}

\begin{abstract}
This study explored local wisdom and culture in Bengkulu that are implemented in reading materials. The objective of this investigation was to create materials of reading that depend on the local wisdom of Bengkulu. In this study, the research design used was a Research and Development (R\&D). The subject of this study was the fourth-semester understudies at the English Study Program of Prof Dr Hazairin SH University. The data was taken through validation sheets. A descriptive analysis was used to analyze the data. Based on the analysis result, $80 \%$ materials components were valid. It tends to be presumed that the materials of teaching reading developed by the researchers are in the feasible classification and can be used by the students in reading activities.
\end{abstract}

Keywords: Reading material, Local wisdom, Reading skill.

\section{INTRODUCTION}

Reading is one of the most necessary abilities in studying English. Understudies who decide to join an English learning must be dominant in this ability due to the fact by way of conquering this understanding expertise; they may enhance their understanding also get a great deal of information [1]. In a second or foreign language learning, reading is fundamental expertise for understudies of English [2]. With lots of reading, readers also can gain a lot of knowledge. Readers elevate out know-how of the system in writing, information on the language, and the potential to interpret meaning from a text. Reading is a cycle of acquiring importance from composed content [3]. Furthermore, "reading is a procedure between the reader and the text that leads to automaticity" [4]. In reading, a reader can begin by looking at the printed word, understand the meaning, and interpret the information by using their knowledge. Besides, this activity is an energetic ability, the spot the reader interfaces with the content, and somewhat the scientist [5].

English as a foreign language that is widely used can make a significant contribution. People use this language in communicating widely with others from all around the nations [6]. It is not solely applied in the formal subject but also in different casual things. In developing countries, English is the only language used for the purposes of the state and the people. The world today is growing rapidly in every aspect, interaction over countries is done in English, and not a single country can exclude English as an international communication tool [7]. There is no other language as a medium of association, a medium for increasing living standards, and a medium for self-formation. For some countries, English is a legacy from our ancestors. However, for other countries, English was the language brought by colonial such as England. In other words, English is a second language.

As residents who live in areas that have historical tourism destinations, young people in Bengkulu are required to have competency in English. This is because as a tourism destination. Everyone is expected to be able to provide correct information to foreigners about Bengkulu so that they do not lose the opportunity to get a job in the world of tourism, public service agencies, and government agencies related to tourism. In order to be able to provide this information, English proficiency and knowledge of Bengkulu culture are required. Culture is one of the essential factors in getting to know a language [8]. Also, "It is more valuable to develop reading materials that suit students' background knowledge, experience, interest, emotion, and culture" [9]. To achieve this purpose, the authors try to include local wisdom-based texts in the reading subject. Thus, it is hoped that students will have competence in English and an understanding of Bengkulu culture because the importance of keeping local knowledge and also a local way of life in educating foreign languages cannot be ignored. The absence of an English learning textbook that includes 
elements of Bengkulu culture is the right urgency why this research was conducted.

\section{RESEARCH METHOD}

In accordance with the problem and research objectives, this research was designed as Research and Development. It is the research carried out intending to produce materials, both in the structure of software or hardware [10]. The ADDIE model was used as model of development in this research. Research procedures are given in the following figure.

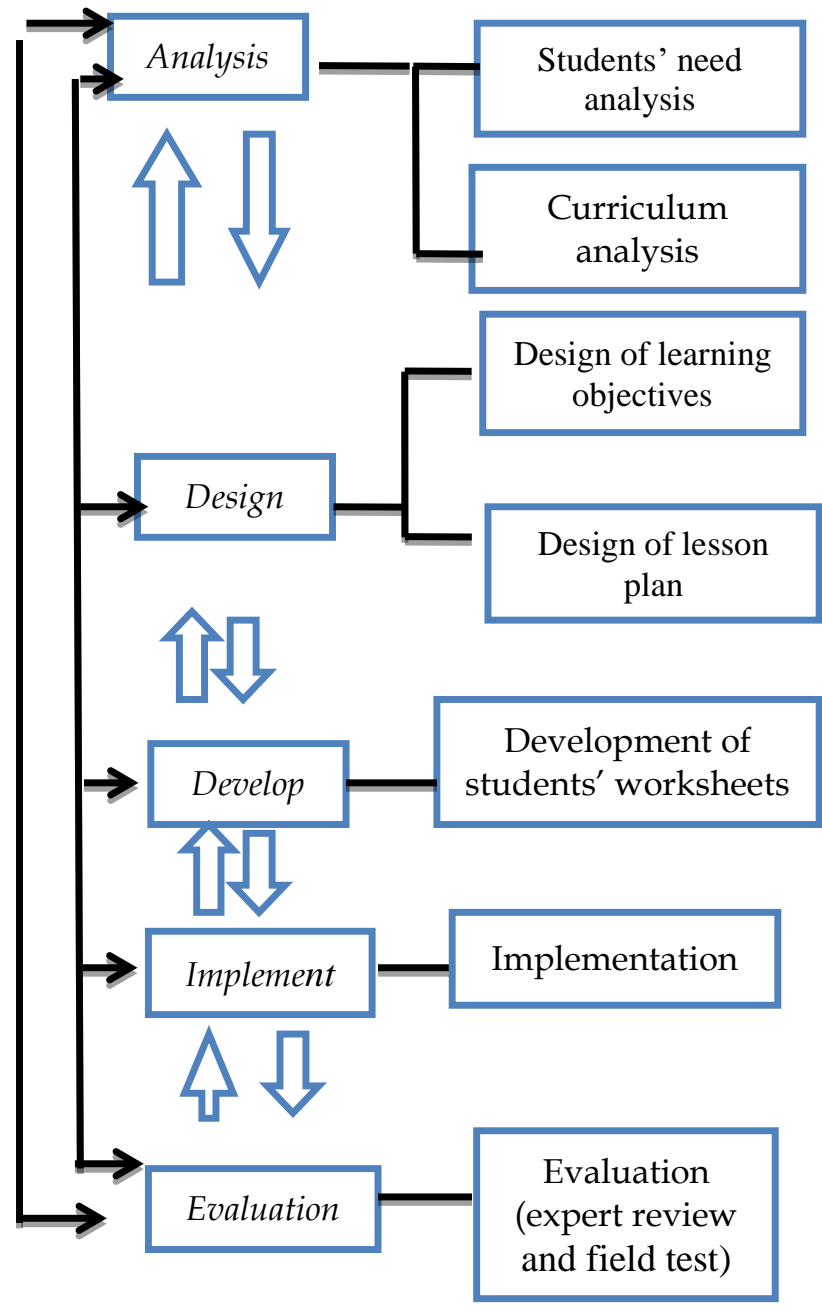

Figure 1 Diagram development ADDIE Model.

Addie model consists of five major steps [11]. They are: step 1 is Analysis. It consists of how to define the problem and the appropriate solution and to determine the students' competency. Step 2 is Design. This step requires a clarification of learning programs that are designed so that the program can achieve the expected learning objective. In this step, researchers determine specific competencies, models, teaching materials, and learning models. Step 3 is Development. In this step, the activities undertaken are producing programs and teaching materials to be used in reading materials. Step
4 is Implementation. This step is to improve the approaches for training facilitators and learners. Training facilitators cowl the direction curriculum, getting to know outcomes, method of delivery, and testing strategies. Implementation includes evaluation of the design. Step 5 is Evaluation. The evaluation step consists of two parts: formative and summative. Formative evaluation is presenting each step of the ADDIE process.

In this study, researchers conducted the research to the development step. It was due to the limitations of time, condition, and cost that are provided.

\section{RESULTS AND DISCUSSION}

The development of local wisdom-based reading materials is intended to produce a product in the form of valid reading material for the fourth-semester understudies of Prof Dr Hazairin SH University. This reading material is based on Bengkulu local wisdom to introduce local wisdom to students. This reading material helps students to get to know local wisdom and its values so that students can get to know, understand and foster a love for local potential, and participate in preserving local wisdom. Therefore, the need for reading material based on local wisdom is very much needed. The following are the results of the research obtained from the validation sheet.

\subsection{Validation of Semester Lesson Plans (RPS)}

Validation or approval is a genuine or invalid assertion from an expert principally dependent on the appraisal of the number of viewpoints that are contained in the approval sheet and the rightness of the substance material. Each instructor in a tutoring unit is obliged to collect a whole and orderly lesson plan so that gaining knowledge of emphasizes the development and improvement of pupil mindsets, particularly studentcentered getting to know to participate actively, interactively, creatively, in team-based, multimediabased, indispensable learning, independence in accordance to talent, interests, and bodily and psychological improvement of students.

As per the rules in preparing the higher education curriculum of the Ministry of Research, Technology and Education, the Directorate General of Learning and Student Affairs, the Directorate of Learning, 2016 states that the readiness of the RPS contains a few significant components including the study program name, the code and name of the course, semester, courses credits, lecturer or adviser name, graduate learning outcomes that are assigned to courses, last capacities arranged at each learning stage, materials of learning, methods of learning, time, student learning experience, criteria, indicators, weighting of assessments, and a list of references. The RPS 
developed is based on local wisdom. Moreover, the RPS that has been created through the method of the scientist is approved to allow an assessment and contribution to the lesson plan of semester (RPS).

The main components that are surveyed contrary to the RPS that have been created and the impacts of the RPS practicality assessment utilizing the instrument can be found in the table 1 below:

Table 1. Validation Assessment Results of RPS

\begin{tabular}{|c|c|c|c|c|c|}
\hline \multirow{2}{*}{ Rated aspect } & \multicolumn{4}{|c|}{ Score } & \multirow[b]{2}{*}{5} \\
\hline & 1 & 2 & 3 & 4 & \\
\hline $\begin{array}{l}\text { Write down the names of } \\
\text { subjects }\end{array}$ & & & & & $\sqrt{ }$ \\
\hline Write the name of the lecturer & & & & & $\sqrt{ }$ \\
\hline $\begin{array}{l}\text { Write down the assessment } \\
\text { and semester }\end{array}$ & & & & & $\sqrt{ }$ \\
\hline $\begin{array}{l}\text { Write down the learning } \\
\text { target of the Study Program }\end{array}$ & & & & & $\sqrt{ }$ \\
\hline $\begin{array}{l}\text { Write down the learning } \\
\text { target of the course }\end{array}$ & & & & & $\sqrt{ }$ \\
\hline Write down the references & & & $\sqrt{ }$ & & \\
\hline $\begin{array}{l}\text { Write down the learning } \\
\text { outcomes }\end{array}$ & & & & & $\sqrt{ }$ \\
\hline $\begin{array}{l}\text { Write down the operational } \\
\text { measures }\end{array}$ & & & & & $\sqrt{ }$ \\
\hline $\begin{array}{l}\text { Write down the time } \\
\text { allocation }\end{array}$ & & & & & $\sqrt{ }$ \\
\hline $\begin{array}{l}\text { Write down the learning } \\
\text { experience }\end{array}$ & & & & $\sqrt{ }$ & \\
\hline $\begin{array}{l}\text { Write down the assessment } \\
\text { criteria or indicators }\end{array}$ & & & & $\sqrt{ }$ & \\
\hline $\begin{array}{l}\text { Write down the assessment of } \\
\text { each meeting }\end{array}$ & & $\sqrt{ }$ & & & \\
\hline
\end{tabular}

In light of the aftereffects of the appraisal of $80 \%$ of all parts of the RPS are legitimate. The result showed that achievement indicators already fulfilled $75 \% \geq[12]$. It tends to be inferred that the RPS created by specialists is in the appropriate classification to be continued in limited class trials.

\subsection{Validation of Teaching Materials}

The materials of teaching are utilized as a kind of perspective in getting to know each exercises in type and in unbiased learning, both in personal and in gatherings. The instructing materials utilized are reading materials created by the specialist. Instructing materials that have been created by analysts are then approved prior to being given to understudies. The aftereffects of the appraisal can be found in Table 2 .

In light of the aftereffects of the evaluation of $80 \%$ of all parts of the teaching materials are legitimate and it tends to be reasoned that the instructing material created via the scientist is in the possible class. Instructing materials that have been created by scientists are approved by specialists.
The outcomes of the feasibility appraisal of the teaching materials that have been created can be inferred that the instructing substances are in the possible class to be utilized or given to understudies.

Table 2. Results of Teaching Material Assessment

\begin{tabular}{lcc}
\hline \multicolumn{1}{c}{ Rated aspect } & Value & Category \\
\hline $\begin{array}{l}\text { Material } \\
\text { coverage } \\
\text { Material } \\
\text { accuracy }\end{array}$ & 4 & Good \\
$\begin{array}{l}\text { Curiosity } \\
\text { aroused }\end{array}$ & 4 & Good Enough \\
$\begin{array}{l}\text { Teaching } \\
\text { reading skills }\end{array}$ & 4 & Good \\
$\begin{array}{l}\text { Language } \\
\text { according to } \\
\text { student } \\
\text { development } \\
\text { Communicative }\end{array}$ & 4 & Good \\
$\begin{array}{l}\text { In accordance } \\
\text { with English }\end{array}$ & 3 & Good Enough \\
rules & 4 & Good \\
\hline
\end{tabular}

Table 3. The assessment of learning outcomes tests

\begin{tabular}{|c|c|c|}
\hline \multicolumn{2}{|c|}{ Content Validity } & \multirow{2}{*}{$\begin{array}{c}\text { Language and Writing } \\
\text { the questions } \\
\text { Information }\end{array}$} \\
\hline Value & Information & \\
\hline 4 & Valid & $\begin{array}{c}\text { Very understandable the } \\
\text { point }\end{array}$ \\
\hline 4 & Valid & $\begin{array}{c}\text { Very understandable the } \\
\text { point }\end{array}$ \\
\hline 3 & Valid & $\begin{array}{l}\text { Can be understood the } \\
\text { point }\end{array}$ \\
\hline 4 & Valid & $\begin{array}{l}\text { Very understandable the } \\
\text { point }\end{array}$ \\
\hline 3 & Valid & $\begin{array}{l}\text { Can be understood the } \\
\text { point }\end{array}$ \\
\hline 4 & Valid & $\begin{array}{l}\text { Very understandable the } \\
\text { point }\end{array}$ \\
\hline 4 & Valid & $\begin{array}{l}\text { Very understandable the } \\
\text { point }\end{array}$ \\
\hline 4 & Valid & $\begin{array}{l}\text { Very understandable the } \\
\text { point }\end{array}$ \\
\hline 4 & Valid & $\begin{array}{l}\text { Very understandable the } \\
\text { point }\end{array}$ \\
\hline 3 & Valid & $\begin{array}{l}\text { Can be understood the } \\
\text { point }\end{array}$ \\
\hline
\end{tabular}

\subsection{Assessment of Learning Outcomes Tests}

Learning result appraisals are made dependent on predetermined models, explicitly dependent on the markers to be done in the studying course. The construction of the test utilized is a description. The rationale of making mastery studying effects tests as depictions is to make understudies can plan answers with their genuine beliefs, done speculating answers, the level of truth and precision of undergrads can be considered from the sentence. The noticed learning results incorporate information skills. The instrument 
for evaluating understudy learning results is shown in the table 3 .

Based on the consequences of the assessment, $92.5 \%$ of all elements of the getting to know outcome check are valid. It can be concluded that the studying results take a look at developed through the researcher is valid and possible to continue in the improvement test.

\section{CONCLUSION}

The validity of the reading materials based on nearby wisdom that have been created in the components of the Lesson Plan of the Semester (RPS), teaching materials, and studying outcome tests is legitimate essentially dependent on the approval results.

\section{ACKNOWLEDGMENTS}

The authors acknowledge the fourth-semester undergraduate students at the English Study Program of Prof Dr Hazairin SH University who help the writers to finish this research and also for Directorate of Research and Community Service who have funded this research.

\section{REFERENCES}

[1] Utami E, Yosi Marita. Developing Reading Material Based Think-Pair-Share Model to Enhance Students' Reading Skill on Fourth Semester English Students of Prof. Dr. Hazairin, SH University. Journal of English Education and Linguistics, vol 2, no 1, 2018, p.40-48.

[2] Utami Elva. The Implementing of Think Pair Share Strategy to Improve Students Reading Comprehension at Fourth Semester of English Study Program of Prof. Dr. Hazairin, SH University.Edu-Ling Journal P-ISSN 2614-7343 Vol. 1, No. 1, December 2017. p.25-32.
[3] William E.J. 1999. Development reading assessment reliability study. http://www.pearsonlearning.com/correlation/rsp/D $\mathrm{RA} / \mathrm{doc}$

[4] Alyousef, H. S. 2006. Teaching reading comprehension to ESL/EFL Learners. Journal of Language and Learning, 5(1), 379-380.

[5] Joycey, Ed. 2006. Reading Comprehension : An Interactive Process. 9th February. http//ilciral.com/737/1017/-21k

[6] Lubis A A, Pratawati F M, Suseno A. Designing English Materials for Psychology: A Case Study. Proceeding of The2nd International Language and Language Teaching Conference Sinata Dharma University, Yogyakarta. 2015

[7] Azizah Nurul. Developing English Learning Materials For Students of HAJJ And Umroh Management (HUM) Departement of IAIN Metro. An Undergradute Thesis. 2019.

[8] Agustina L, Harahap A, Syahrial. Developing Reading Material Based on Local Culture For Junior High School in Kabupaten Rejang Lebong. Journal of Applied Linguistic and Literature, vol 3 , no. 1,2018

[9] J Mukundan, A Zarifi, SAR Kalajahi. Developing Reading Materials For ESL Learners in A Maryam, Z Mitra, F Akram, RK Hamid (Eds). Issues in Materials Development. Sense Publisher Rotterdam.

[10] Sugiyono. Memahami Penelitian Kuantitatif. Bandung: Alfabeta, 2012.

[11] Sugiyono. Metode Penelitian Kuantitatif Kualitatif dan R\&D Bandung: Alfabeta, 2015.

[12] Borich Ibrahim. Pembelajaran Kooperatif. Surabaya:UNESA-University Press. 2000 